\title{
The Search for a Stable Money Demand Function for Pakistan: An Application of the Method of Cointegration
}

\author{
AKHTAR HOSSAIN
}

\section{INTRODUCTION}

Despite an impressive number of studies on money demand in Pakistan since the early 1970s, the question of stability of the money demand function did not receive much attention. This paper examines the question of whether there exists a stable money demand function in Pakistan. The novelty of the study comes from the application of the method of cointegration to Pakistani annual data over 1951-91. ${ }^{1}$ The empirical findings of this study are somewhat different from those of earlier studies on money demand in Pakistan and have monetary policy implications. However, besides some inherent shortcomings of the method of cointegration, one possible weakness of the paper is the use of data which extend over the 1950s and 1960 s when Bangladesh was a part of Pakistan. It creates an unavoidable problem of data conformability. It induced me to take the risk of being somewhat complacent about the sample size as I report empirical results for a shorter sample period 1972-91. One consolation is that empirical findings for this sub-sample appear qualitatively better than those obtained for the full sample period.

\section{TESTS FOR UNIT ROOTS}

A long run money demand function for a developing country can be specified

Akhtar Hossain is a Lecturer in Economics at the University of Newcastle, Australia.

Author's Note: This is an abridged version of a long and expanded paper on this topic. I since rely thank Professor Colm Kearney and Dr'Tony Webber for their substantive comments on an earlier draft of the paper. I acknowledge the receipt of a travel grant from the Research Management Committee of the University of Newcastie for attending the conference and thank both the Pakistan Society of Development Economists and the Pakistan Institute of Development Economics for their hospitality during the conference.

${ }^{1}$ The basic data are taken from various issues of both International Financial Statistics Yearbook and the State Bank of Pakistan Bulletin and also from Khan and Bergan (1966). The data set used for the study and their detailed sources may be available from the author upon request. 
as: $\ln m_{t}=\alpha 0+\alpha 1 \ln y_{t}+\alpha 2 \ln i n t+\alpha 3 \pi^{e}$, where $\ln$ is natural logarithmic operator, $m$ is real (narrow or broad) money balances, $y$ is real income/output (measured or permanent), int is a representative interest rate, $\pi^{e}$ is expected inflation and $\alpha$ are structural parameters with the expected signs: $\alpha 1>0$ and $\alpha 2, \alpha 3<0$. Based on this specification the following variables have been subjected to unit root testing to determine their eligibility to form a long run equilibrium relationship.

\section{Definitions of Real Money Balances}

$\ln (M 1 / C P I)=$ natural $\log$ of real narrow money balances (the stock of narrow money ( $M 1)$, Millions of Rupees, deflated by the consumer price index $(C P I), 1985=1.00)$.

$\ln (M 2 / C P I)=$ natural $\log$ of real broad money balances (the stock of narrow money plus quasi-money $(M 2)$, Millions of Rupees, deflated by the consumer price index $(C P I), 1985=1.00)$.

\section{Definition of Scale Variable}

In $R G D P=$ natural log of gross domestic product, Millions of Rupees, at 1985 prices.

\section{Definitions of Opportunity Cost Variables}

In $G B Y=$ natural log of yield on government bonds (percent).

In $M R$ = natural log of the market call rate of interest (percent).

$\pi=$ natural logarithmic difference of the consumer price index $(1985=100)$ multiplied by 100 .

\section{Unit Root Tests Results}

Appendix Table 1 reports the test results for a unit root in each of the variables in the money demand function. It shows that the null hypothesis that real money balances (narrow or broad), real output, the yield on government bonds and the market call rate of interest have a unit root cannot be rejected at the 1 percent level. ${ }^{2}$ However, the hypothesis that inflation has a unit root can be rejected by the

${ }^{2}$ By the ADF(1) test, the hypothesis that real broad money balances have a unit root is rejected at the 5 percent level. 
$\mathrm{DF}$ and $\mathrm{ADF}(1)$ tests at the 10 percent level. ${ }^{3}$ For both real money balances (narrow or broad) and real output, even though the hypothesis that $\beta 0=\beta 1=\beta 2=0$ is rejected at the 5 percent level, the hypothesis that $\beta 1=\beta 2=0$ cannot be rejected. It suggests that the log of real money balances (narrow or broad) and the log of real output follow a random walk with a drift. In the cases of yield on government bonds and the market call rate of interest, the hypothesis that $\beta 0=\beta 1=\beta 2=0$ cannot be rejected at the 5 percent level. It suggests that the log of yield on government bonds and the $\log$ of the market call rate of interest follow a random walk with no drift.

\section{TESTS FOR COINTEGRATION}

The presence of a unit root in each of real narrow and broad money balances, real output and the interest rate suggests that they are eligible to form a cointegrating set or long run equilibrium relationship. The inflation rate is not however eligible to form a cointegral relationship with any of the above variables because it appears to be integrated of order zero I $(0)$.

Besides the DF and ADF tests, the Cointegrating Regression Durbin-Watson (CRDW) test has been conducted to determine the presence of cointegration between each of real narrow and broad money balances and real output (with or without the interest rate). Appendix Table 2 reports the cointegration tests results. For the two variable case the CRDW and ADF tests results for 1951-91 suggest that there is a cointegral relationship between the log of real narrow money balances and the log of real output. However, such a relationship does not exist between the log of real broad money balances and the log of real output. The coefficient of the interest rate bears a positive sign in each of real narrow and broad money balances cointegrating regressions for 1951-91, which indicates that the interest rate perhaps does not form a cointegral relationship with each of real narrow and broad money balances. Even though the practice of including dummy variables in a cointegrating regression to capture extraordinary events has come under criticism [Engle and Granger (1991); Muscatelli and Hurn (1992)], in the cointegrating regression for 1951-91 a dummy variable has been used to capture the break-up of the country in 1971. The inclusion of such a dummy did not give any better results in rejecting the

${ }^{3}$ Note that the $\Phi 2$ and $\Phi 3$ tests do not reject the null hypothesis that inflation has a unit root with a drift. When the inflation rate is calculated from the wholesale price index, the following values are obtained for the $\mathrm{DF}, \mathrm{ADF}(1), \mathrm{ADF}(2), \Phi 2$ and $\Phi 3$ test statistics: $\mathrm{DF}=-4.5, \mathrm{ADF}(1)=-5.8$, $\operatorname{ADF}(2)=-3.3, \Phi 2=4.4$ and $\Phi 3=6.3$. From these results it appears that inflation probably does not have a unit root. 
null hypothesis of non-cointegration. ${ }^{4}$

For the sub-sample 1972-91 the cointegration tests results are qualitatively better. All the tests results indicate a cointegral relationship among real money balances (narrow or broad), real output and the interest rate. Importantly, the coefficient of the interest rate bears a negative sign in the cointegrating regression. However, because of small sample size, the cointegral relationship among these variables cannot be formally tested.

\section{The Johansen Cointegration Tests}

The Engle-Granger procedure of testing for cointegration has a number of shortcomings. One major shortcoming of the Engle-Granger approach is that it tests for the presence of a unique cointegrating relationship even though in the case of more than two variables there is always a possibility of multiple cointegration relationships [Muscatelli and Hurn (1992)]. The possibility of multiple cointegration relationships can be examined within a multivariate framework proposed by Johansen (1988) and Johansen and Juselius (1990). Johansen and Juselius (1990) propose two likelihood ratio tests for the number of cointegrating vectors: the trace test and the maximum eigenvalue test. The trace test evaluates the null hypothesis that there are at most $r$ cointegrating vectors against the general alternative, while the maximum eigenvalue test evaluates the null hypothesis that there are $r$ cointegrating vectors against the alternative of $r+1$. Johansen and Juselius (1990) also provide a methodology for testing hypotheses about estimated coefficients of cointegrating vectors based on likelihood ratio tests with standard chi-squared distributions.

Appendix Table 3 reports the Johansen cointegration tests results among real narrow or broad money balances, real output and the market call rate of interest. Both the trace and maximum eigenvalue tests are reported to determine the number of cointegrating vectors.

The trace test results reject the null hypothesis of $r=0$. The null hypothesis that $r \leq 1$ however cannot be rejected. The maximum eigenvalue test provides an alternative check for the number of cointegrating vectors. The results of the maximum eigenvalue test accord well with those of the trace test and suggest that there

4Engle and Granger (1991) suggest that when the individual series are I(1) with a drift, one may include a time trend in the cointegrating regression which is equivalent to detrending the series first. In the case of Pakistan, each of real narrow and broad money balances and real output are found to be I(1) with a drift. A trend was therefore included in the cointegrating regression, but the overall cointegration tests results did not change in qualitative sense. 
is one cointegrating vector. The fact that the maximum eigenvalue test rejects the null is noteworthy because Johansen and Juselius (1990) note that the power of the trace test is relatively low.

Appendix Table 5 reports the implied long run income and interest elasticities of demand for real money balances (obtained after normalising the cointegrating vectors). It shows that the interest elasticity of demand for each of real narrow and broad money balances is positive for 1953-91. Because this finding is theoretically inconsistent, the Johansen cointegration tests have been conducted between the log of real narrow or broad money balances and the log of real output. Appendix Table 4 reports the tests results. Both the trace and maximum eigenvalue tests results suggest that there is one cointegrating vector between the log of real narrow or broad money balances and the log of real output.

From the unrestrained cointegrating vectors for 1953-91 the following two normalised equations can be selected as long run money demand equations because they are consistent with economic theory and the implied income elasticities make economic sense. For example, the value of income elasticity of demand for real narrow money balances is 1.17 , while the value of income elasticity of demand for real broad money balances is 1.30 . A likelihood ratio test has been conducted for the parameter restriction that the value of income elasticity of demand for each of real narrow and broad money balances is one. This restriction is rejected for each of real narrow and broad money balances.

Sample: 1953-91

$$
\begin{aligned}
& \ln (\mathrm{M} 1 / \mathrm{CPI})=\text { constant }+1.17 \ln \mathrm{RGDP} \\
& \ln (\mathrm{M} 2 / \mathrm{CPI})=\text { constant }+1.30 \ln \mathrm{RGDP}
\end{aligned}
$$

\section{Sample: 1972-91}

\section{Two Cointegrating Vectors}

The Johansen cointegration tests results for 1972-91 in Appendix Table 4 suggest that there are two cointegrating vectors. As indicated earlier, the strength of the Johansen cointegration testing methodology over the Engle-Granger one is its ability to detect multiple cointegration when there are more than two variables in the cointegrating set. This strength of the Johansen methodology is associated with one of its weaknesses that there is no satisfactory way of interpreting multiple cointegrated vectors in economic terms [Muscatelli and Hurn (1992)].

From the unrestrained cointegrating vectors for 1972-91 the following two normalised equations can be selected as long run money demand functions because 
they are consistent with economic theory and the implied income and interest elasticities make economic sense. The value of income elasticity of demand for real narrow money balances is lower than one, while the value of income elasticity of demand for real broad money balances is around one. The absolute value of interest elasticity of demand for real narrow money balances is found higher than that for real broad money balances. Such a difference in the values of interest elasticities of demand for real narrow and broad money balances has been found in studies, such as Hafer and Jansen (1991), for other countries.

\section{Sample: 1972-91}

$$
\begin{array}{llll}
\ln (\mathrm{M} 1 / \mathrm{CPI})= & \text { constant } & +0.86 \ln \mathrm{RGDP} & -0.54 \ln \mathrm{MR} \\
\ln (\mathrm{M} 2 / \mathrm{CPI})= & \text { constant } & +1.07 \ln \mathrm{RGDP} & -0.05 \ln \mathrm{MR}
\end{array}
$$

\section{SUMMARY AND CONCLUSION}

This paper has examined the question of whether there exists a stable money demand function in Pakistan for 1951-91 by applying the method of cointegration. Tests for unit roots suggest that each of real narrow and broad money balances, real output and a representative interest rate (the market call rate of interest or the yield on government bonds), but not inflation, appear to have a unit root. Based on these unit root tests results, the Engle-Granger procedure has been adopted initially to test for cointegration among real narrow or broad money balances, real output and a measure of the interest rate. As the CRDW, DF and ADF tests results have given conflicting results about the presence of a cointegral relationship among real narrow or broad money balances, real output and the interest rate, the Johansen multivariate cointegration tests have been conducted to resolve the issue. The latter tests have shown that there is a cointegral relationship between the log of real narrow or board money balances and the log of real output for 1953-91. The likelihood ratio test results suggest that the value of income elasticity of demand for each of real narrow and broad money balances is greater than one. However, for the sub-sample 1972-91, the Johansen cointegration tests results among real narrow or broad money balances, real output and the market call rate of interest suggest the presence of two cointegrating vectors. From the two unconstrained cointegrating vectors one normalised equation has been derived and interpreted as the long run money demand function as it is consistent with economic theory and the implied income and interest elasticities of demand for money make economic sense. However, because of small sample size, the tests results for 1972-91, although qualitatively superior to those

wined for the full sample period, are to he used cautiously. 
The presence of a cointegral relationship between each of real narrow and broad money balances and real output is consistent with the notion of a stable long run money demand relationship, albeit in a limited sense. ${ }^{5}$ An implication of a stable money demand function is that there is potential for achieving price stability by controlling the growth rate of the money supply. The overall empirical results suggest that the narrow money demand function is more stable than the broad money demand function and hence a narrow monetary aggregate may be used for monetary targeting in Pakistan. ${ }^{6}$ It would however require the monetary authority in Pakistan to consider price stability, instead of a multitude of objectives, as the main objective of monetary policy and to adopt a more flexible exchange rate system in order to ensure control over the stock of money supply.

${ }^{5}$ Long term structural change in the money demand function is sometimes examined by estimating cointegration regressions for two or more sub-samples. Looking at the normalised cointegration vectors for 1953-91 and 1972-91, one would find that the income elasticity of demand for each of real narrow and broad money balances has declined over time that the interest rate has become significant in the money demand function during 1972-91. If the small sample bias is assumed small, then such a result would imply that the long run money demand function in Pakistan has undergone structural change over time. The idea that there exists a stable money demand function should therefore be interpreted in such a way that can accommodate any gradual structural change in parameter values in response to a structural (and institutional) change in the economy. Miller (1991) reports results for the United States which show that the values of income and interest elasticities of demand for real money balances have changed in recent years, possibly because of financial innovation and deregulation.

${ }^{6}$ The presence of any cointegral relationship between money and output would indicate that the velocity of money is stationary. The Dickey-Fuller tests for a unit root in the velocity of money in Pakistan give the following results:

$\begin{array}{lclll}\text { Sample } & \text { Series } & \text { DF } & \text { ADF(1) } & \text { ADF(2) } \\ 1952-91 & \text { Velocity of M1 } & -3.2 & -4.7 & -3.5 \\ 1952-91 & \text { Velocity of M2 } & -2.2 & -3.3 & -2.0\end{array}$

The above unit root tests results provide further evidence that the narrow money deman function in Pakistan is more stable than the broad money demand function. One area of further researcl is to examine the question of whether the velocity of money in Pakistan has any cointegral relationsh: with the interest rate. 
Appendix Table 1

Appendices

The Time Series Properties of Variables in the Money Demand Function

\begin{tabular}{lllllll}
\hline Sample & Series & DF & ADF(1) & ADF(2) & Ф2 & Ф3 \\
\hline $1952-91$ & $\ln (\mathrm{M} 1 / \mathrm{CPI})$ & -2.6 & -2.8 & -2.0 & 5.6 & 2.5 \\
$1952-91$ & $\ln (\mathrm{M} 2 / \mathrm{CPI})$ & -3.0 & -3.7 & -2.7 & 7.6 & 3.5 \\
$1951-91$ & $\ln \mathrm{RGDP}$ & -0.6 & -0.6 & -0.2 & 6.3 & 1.9 \\
$1952-91$ & $\ln$ GBY & -1.0 & -0.9 & -1.0 & 1.3 & 0.9 \\
$1952-91$ & $\ln \mathrm{MR}$ & -2.4 & -1.3 & -1.2 & 3.5 & 3.3 \\
$1952-91$ & $\pi$ & -3.4 & -3.5 & -2.6 & 2.2 & 3.3 \\
$1953-91$ & $\Delta \ln (\mathrm{M} 1 / \mathrm{CPI})$ & -5.9 & & & & \\
$1953-91$ & $\Delta \ln (\mathrm{M} 2 / \mathrm{CPI})$ & -5.9 & & & & \\
$1952-91$ & $\Delta \ln \mathrm{RGDP}$ & -5.6 & & & & \\
$1953-91$ & $\Delta \ln$ GBY & -6.1 & & & & \\
$1953-91$ & $\Delta \ln \mathrm{MR}$ & -9.0 & & & & \\
$1953-91$ & $\Delta \pi$ & -6.7 & & & & \\
\hline
\end{tabular}

Source : Fuller (1976:373); Dickey and Fuller (1981, Tables V and VI:1063). Critical values in parentheses for the DF/ADF statistics are for cases where the regression equations are estimated with a constant, but no time trend.

Notes: + The test for a unit root in the level form is based on the regression equation: $\Delta z_{t}=\beta 0+\beta 1 t+\beta 2 z_{t-1}+\Sigma \delta i z_{t-1}+$ error term, where $z$ is the generic term for the variable used for unit root testing; $\Delta z_{t}=z_{t}-z_{t-1} ; t$ is a linear time trend; $\beta 0$ is a column of ones, and $i$ $=1,2, \ldots 1$. The Dickey-Fuller (DF) test in the level form is based on the above regression with rest riction that $\Sigma \delta i=0$. The test of the random walk hypothesis is the test of the zero restriction on $\beta 2$. When the null hypothesis of unit root was not rejected, a regression of the form, $\Delta^{2} z_{t}=\gamma 0+\gamma 1 \Delta z_{t-1}+$ error term, was run and then the null hypothesis $\gamma 1=0$ was tested against the alternative $\gamma 1<0$.

$++\mathrm{ADF}(1)$ is the augmented Dickey-Fuller test statistic with a lag length of $1=1,2$.

+++ The statistics $\Phi$ and $\Phi$ are for testing the hypotheses $(\beta 0=\beta 1=\beta 2=0)$ and $(\beta 1=\beta 2=0)$ in the ADF specification with the lag length of $1=2$.

! The reported sample period is for the DF test statistic. For the ADF(1) or ADF(2) test statistic, the sample period of estimation is reduced by 1 or 2 because of the inclusion of lagged dependent variable(s) in the estimating equation.

\begin{tabular}{|c|c|c|c|c|c|}
\hline \multicolumn{2}{|c|}{ !!Critical Values } & \multicolumn{2}{|c|}{ DF/ADF } & $\Phi 2$ & $\Phi 3$ \\
\hline $\begin{array}{c}\text { Sample } \\
\text { Size }\end{array}$ & $1 \%$ & $5 \%$ & $10 \%$ & $\begin{array}{r}P \\
a \\
0.95\end{array}$ & $\begin{array}{l}f \\
\text { ue } \\
0.95\end{array}$ \\
\hline 25 & $-4.38(-3.75)$ & $-3.60(-3.00)$ & $-3.24(-2.63)$ & 5.68 & 7.24 \\
\hline 50 & $-4.15(-3.58)$ & $-3.50(-2.93)$ & $-3.18(-2.60)$ & 5.13 & 6.73 \\
\hline
\end{tabular}


Appendix Table 2-A

Cointegration Regressions of Real Money Balances on Real Output and the Interest Rate

\begin{tabular}{|c|c|c|c|c|c|c|c|}
\hline \multirow{2}{*}{$\begin{array}{l}\text { Dependent } \\
\text { Variable }\end{array}$} & \multicolumn{2}{|c|}{ Coefficient on } & \multirow[b]{2}{*}{$R^{2}$} & \multirow[b]{2}{*}{ CRDW } & \multirow[b]{2}{*}{ DF } & \multirow[b]{2}{*}{$\mathrm{ADF}(1)$} & \multirow[b]{2}{*}{$\operatorname{ADF}(2)$} \\
\hline & In RGDP & $\ln G B Y$ & & & & & \\
\hline \multicolumn{2}{|c|}{$\begin{array}{ll}\text { Sample: 1951-91 } \\
\ln (\mathrm{MI} / \mathrm{CPI}) & 1.09 \\
\ln (\mathrm{M} 1 / \mathrm{CPI}) & 1.11\end{array}$} & 0.03 & $\begin{array}{l}0.97 \\
0.97\end{array}$ & $\begin{array}{l}0.81 \\
0.82\end{array}$ & $\begin{array}{l}-3.1 \\
-3.2\end{array}$ & $\begin{array}{l}-4.7 \\
-4.8\end{array}$ & $\begin{array}{l}-3.4 \\
-3.5\end{array}$ \\
\hline \multirow[t]{3}{*}{$\begin{array}{l}\text { Sample: } 1972- \\
\ln (\mathrm{M} 1 / \mathrm{CPI}) \\
\ln (\mathrm{M} 1 / \mathrm{CPI})\end{array}$} & $\begin{array}{rr} & \\
& \\
1.01 & \\
& 1.05\end{array}$ & -0.13 & $\begin{array}{l}0.91 \\
0.91\end{array}$ & $\begin{array}{l}1.00 \\
0.82\end{array}$ & $\begin{array}{l}-3.9 \\
-4.0\end{array}$ & $\begin{array}{l}-5.4 \\
-5.2\end{array}$ & $\begin{array}{l}-2.9 \\
-2.3\end{array}$ \\
\hline & \multicolumn{2}{|c|}{ Coefficient on } & & & & & \\
\hline & $\ln \mathrm{RGDP}$ & $\ln \mathrm{MR}$ & & & & & \\
\hline $\begin{array}{l}\text { Sample: 1951-91 } \\
\text { In (M1/CPI) }\end{array}$ & 1.11 & 0.003 & 0.97 & 0.83 & -3.2 & -4.8 & -3.5 \\
\hline $\begin{array}{l}\text { Sample: 1972-91 } \\
\text { ln (M1/CPI) }\end{array}$ & 0.95 & -0.46 & 0.97 & 1.03 & -2.5 & -3.3 & -3.0 \\
\hline \multicolumn{8}{|l|}{ Critical Values } \\
\hline Statistic & \multicolumn{2}{|c|}{ Sample Size } & \multicolumn{3}{|c|}{$\begin{array}{l}2 \text { Variable Case } \\
\text { (5 Percent Level) }\end{array}$} & \multicolumn{2}{|c|}{$\begin{array}{l}3 \text { Variable Case } \\
\text { (5 Percent Level) }\end{array}$} \\
\hline $\begin{array}{l}\text { CRDW } \\
\text { DF } \\
\text { ADF }\end{array}$ & & $\begin{array}{l}50 \\
50 \\
50 \\
\end{array}$ & & $\begin{array}{r}0.78 \\
-3.67 \\
-3.29 \\
\end{array}$ & & $\begin{array}{r}0.9 \\
-4.1 \\
-3.7 \\
\end{array}$ & \\
\hline
\end{tabular}

Source: Engle and Yoo (1987).

Appendix Table 2-B

Cointegration Regressions of Real Broad Money Balances on

Real Output and the Interest Rate

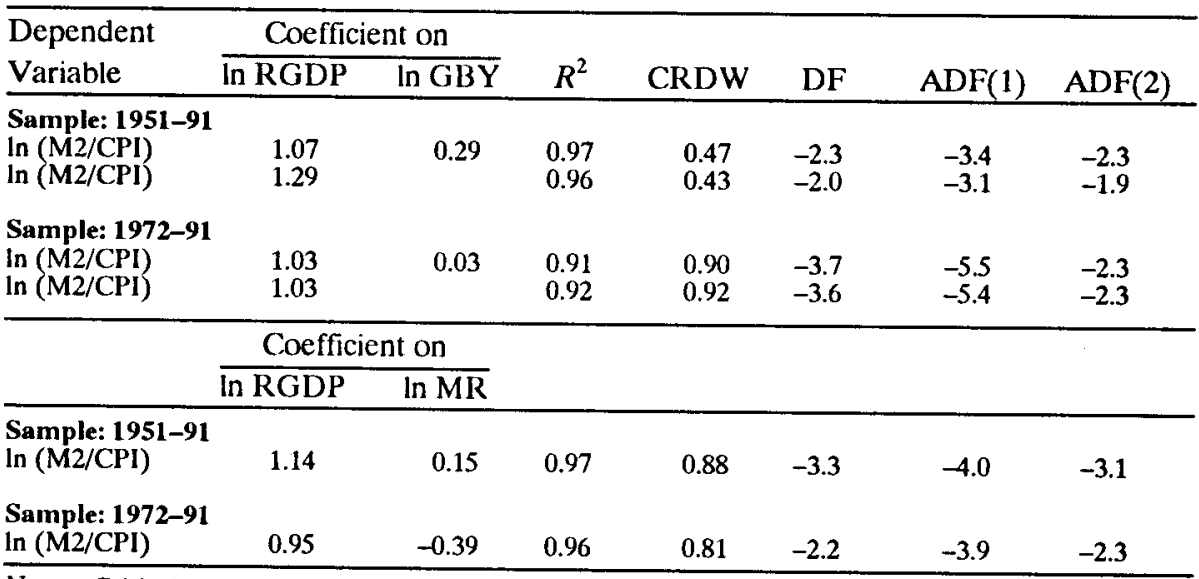

Notes: Critical values are as for Table2-A. 
Appendix Table 3

The Johansen Cointegration Tests Results

A. In (M1/CPI), In RGDP and In MR were used for cointegration tests; Maximum $\mathrm{Lag}$ in VAR $=2$.

Maximal Eigenvalue Test

\begin{tabular}{llccc}
\hline Null & Alternative & \multicolumn{2}{c}{ Test Statistic } & 95\% Critical \\
\cline { 3 - 4 } Hypothesis & Hypothesis & $1953-91$ & $1972-91$ & Value \\
\hline $\mathbf{r}=0$ & $\mathrm{r}=1$ & 29.09 & 25.54 & 21.07 \\
$\mathbf{r} \leq 1$ & $\mathrm{r}=2$ & 4.65 & 15.95 & 14.90 \\
$\mathrm{r} \leq 2$ & $\mathrm{r}=3$ & 1.33 & 0.83 & 8.17 \\
\hline
\end{tabular}

Trace Test

\begin{tabular}{ccccc}
\hline Null & Alternative & \multicolumn{2}{c}{ Test Statistic } & $95 \%$ Critical \\
\cline { 3 - 5 } Hypothesis & Hypothesis & $1953-91$ & $1972-91$ & Value \\
\hline $\mathbf{r}=0$ & $\mathrm{r} \geq 1$ & 35.07 & 42.31 & 31.53 \\
$\mathrm{r} \leq 1$ & $\mathrm{r} \geq 2$ & 5.98 & 16.77 & 17.95 \\
$\mathrm{r} \leq 2$ & $\mathrm{r}=3$ & 1.33 & 0.83 & 8.18 \\
\hline
\end{tabular}

B. In (M2/CPI), ln RGDP and ln MR were used for cointegratin tests; Maximum Lag in VAR $=2$.

Maximum Eigenvalue Test

\begin{tabular}{ccccc}
\hline Null & Alternative & \multicolumn{2}{c}{ Test Statistic } & $95 \%$ Critical \\
\cline { 3 - 5 } Hypothesis & Hypothesis & $1953-91$ & $1972-91$ & Value \\
\hline $\mathbf{r}=0$ & $\mathbf{r}=1$ & 29.91 & 30.27 & 21.07 \\
$\mathbf{r} \leq 1$ & $\mathrm{r}=2$ & 5.16 & 21.90 & 14.90 \\
$\mathrm{r} \leq 2$ & $\mathrm{r}=3$ & 1.14 & 0.01 & 8.18 \\
\hline
\end{tabular}

\section{Trace Test}

\begin{tabular}{ccccc}
\hline Null & Alternative & \multicolumn{2}{c}{ Test Statistic } & $95 \%$ Critical \\
\cline { 3 - 5 } Hypothesis & Hypothesis & $1953-91$ & $1972-91$ & Value \\
\hline $\mathbf{r}=0$ & $\mathrm{r} \geq 1$ & 36.21 & 52.19 & 31.53 \\
$\mathrm{r} \leq 1$ & $\mathrm{r} \geq 2$ & 6.31 & 21.92 & 17.95 \\
$\mathrm{r} \leq 2$ & $\mathrm{r}=3$ & 1.14 & 0.01 & 8.18 \\
\hline
\end{tabular}

Notes: $r$ denotes the number of cointegrating vectors. 
Appendix Table 4

The Johansen Cointegration Tests Results

A. In (M1/CPI), ln RGDP and ln RGDP were used for cointegration tests; Maximum Lag in VAR $=2$.

\section{Maximal Eigenvalue Test}

\begin{tabular}{ccccc}
\hline $\begin{array}{c}\text { Null } \\
\text { Hypothesis }\end{array}$ & $\begin{array}{c}\text { Alternative } \\
\text { Hypothesis }\end{array}$ & \multicolumn{2}{c}{ Test Statistic } & $\begin{array}{c}95 \% \text { Critical } \\
\text { Value }\end{array}$ \\
\hline $\mathbf{r}=0$ & $\mathrm{r}=1$ & 29.16 & $1972-91$ & 14.19 \\
$\mathrm{r}=1$ & $\mathrm{r}=2$ & 3.42 & 122 & 8.08 \\
\hline
\end{tabular}

Trace Test

\begin{tabular}{ccccc}
\hline Null & Alternative & \multicolumn{2}{c}{ Test Statistic } & 95\% Critical \\
\cline { 3 - 5 } Hypothesis & Hypothesis & $1953-91$ & $1972-91$ & Value \\
\hline r $=0$ & r $\geq 1$ & 32.57 & 24.29 & 17.95 \\
r $\leq 1$ & $\mathrm{r} \geq 2$ & 3.42 & 1.22 & 8.18 \\
\hline
\end{tabular}

B. In (M2/CPI) and ln RGDP were used for cointegrating tests; Maximum Lag in $\mathrm{VAR}=2$.

Maximum Eigenvalue Test

\begin{tabular}{ccccc}
\hline Null & Alternative & \multicolumn{2}{c}{ Test Statistic } & $95 \%$ Critical \\
\cline { 3 - 5 } Hypothesis & Hypothesis & $1953-91$ & $1972-91$ & Value \\
\hline $\mathrm{r}=0$ & $\mathrm{r}=1$ & 16.48 & 19.14 & 14.90 \\
$\mathrm{r} \leq 1$ & $\mathrm{r}=2$ & 3.81 & 1.37 & 8.18 \\
\hline
\end{tabular}

Trace Test

\begin{tabular}{llccc}
\hline Null & Alternative & \multicolumn{2}{c}{ Test Statistic } & $95 \%$ Critical \\
Hypothesis & Hypothesis & $1953-91$ & $1972-91$ & Value \\
\hline $\mathbf{r}=0$ & $\mathbf{r} \geq 1$ & 20.29 & 20.51 & 17.95 \\
$\mathrm{r} \leq 1$ & $\mathrm{r} \geq 2$ & 3.81 & 1.37 & 8.18 \\
\hline
\end{tabular}


Appendix Table 5

Cointegrating Vectors and the Implied Long Run Elasticities

\section{A. Cointegrating Vectors}

\begin{tabular}{llrrc}
\hline Sample & Vector & $\ln (\mathrm{M} 1 / \mathrm{CPI})$ & $\ln$ RGDP & $\ln$ MR \\
\hline $1953-91$ & 1 & 1.84 & -2.13 & -0.01 \\
$1953-91$ & 1 & -1.82 & 2.14 & \\
& & & & \\
$1972-91$ & 1 & 0.77 & -1.38 & -0.77 \\
& 2 & -4.48 & 3.86 & -2.43 \\
& & & & \\
\hline Sample & Vector & $\ln (\mathrm{M} 2 / \mathrm{CPI})$ & ln RGDP & $\ln \mathrm{MR}$ \\
\hline $1953-91$ & 1 & 1.59 & -1.86 & -0.28 \\
$1953-91$ & 1 & 1.30 & 1.81 & \\
& & & & \\
$1972-91$ & 1 & -2.54 & 2.74 & -0.13 \\
& 2 & 2.84 & -2.16 & 2.07
\end{tabular}

\section{B. Implied Long Run Elasticities}

\begin{tabular}{lccc}
\hline Sample & Income & Interest Rate & LR Test $\left(\chi^{2}(1)\right)$ \\
\hline & \multicolumn{3}{c}{$\ln (\mathrm{M} 1 / \mathrm{CPI})$} \\
$1953-91$ & 1.16 & 0.007 & \\
$1953-91^{*}$ & 1.17 & & $15.5^{\mathrm{a}}$ \\
& & & \\
$1972-91$ & 1.79 & 0.99 & \\
$1972-91^{*}$ & 0.86 & -0.54 & \\
& & & \\
& \multicolumn{2}{c}{$\ln (\mathrm{M} 2 / \mathrm{CPI})$} & \\
$1953-91$ & 1.16 & 0.17 & \\
$1953-91^{*}$ & 1.38 & & \\
& & & \\
$1972-91^{*}$ & 1.07 & -0.05 & \\
$1972-91$ & 0.76 & -0.73 & \\
\hline
\end{tabular}

Notes: * Represents a cointegrating vector that gives theoretically consistent elasticities.

+The Likelihood ratio test rejects the parameter restriction that the income elasticity of demand for each of real narrow and broad money balances is one $\left(\mu_{y}\right)$.

${ }^{a}$ Denotes statistical significance at the 1 percent level. 


\section{REFERENCES}

Dickey, D. A., and W. A. Fuller (1981) Likelihood Ratio Statistics for Autoregressive Time Series with a Unit Root. Econometrica 50: 1057-72.

Engle, R.F., and B.S. Yoo (1987) Forecasting and Testing in Cointegrated Systems. Journal of Econometrics 35: 143-59.

Engle, R. F., and C. W. J. Granger (1991) Long Run Economic Relationships. Oxford: Oxford University Press.

Fuller, W. A. (1976) Introduction to Statistical Time Series. New York: John Wiley. Hafer, R. W., and D.W. Jansen, (1991) The Demand for Money in the United States: Evidence from Cointegration Tests. Journal of Money, Credit, and Banking 23: 155-68.

Johansen, S. (1988) Statistical Analysis of Cointegration Vectors. Joumal of Economic Dynamics and Control 12: 232-54.

Johansen, S., and K. Juselius (1990) Maximum Likelihood Estimation and Inference on Cointegration with Applications to the Demand for Money. Oxford Bulletin of Economics and Statistics 52: 169-209.

Khan, T. M., and A. Bergan (1966) Measurement of Structural Change in the Pakistan Economy: A Review of the National Income Estimates, 1949-50-196364. The Pakistan Development Review 6: 163-208.

Miller, S. (1991) Monetary Dynamics: An Application of Cointegration and Errorcorrection Modelling. Joumal of Money, Credit, and Banking 23: 139-54.

Muscatelli, V. A., and S. Hurn (1992) Cointegration and Dynamic Time Series Models. Joumal of Economic Surveys 6: 1-43. 


\section{Comments on \\ "The Search for a Stable Money Demand \\ Function for Pakistan: An Application of the \\ Method of Cointegration"}

This paper by Dr Hossain identifies the stability of the money demand function for Pakistan by using the cointegration technique. Conventional econometric techniques can only be applied to stationary variables, therefore, it poses certain problems when applied to variables which are non-stationary in nature. However, recent econometric development in the area of time-series analysis has dealt with such problems in a quite simple but interesting fashion. Now it has been realised that the determination of the long-run relationship in variables being studied, is the primary objective of any economic research, and Dr Hossain has provided an excellent application of the method of cointegration to identify the long-run stable relationship of the money demand function. There are a few comments to be made.

First, Dr Hossain has used yield on government bonds and market call rate of interest as opportunity cost variables in this study and he came up with theoretically inconsistent interest elasticity parameters as the coefficient of the rate of interest bears a positive sign. Also, he does not find any cointegral relationship of the interest rate with each of the real narrow and broad money balances for the full sample period covering the period 1951-91. This perhaps may by due to the choice of the rate of interest variables used in this study i.e., yield on government bonds and the market call rate of interest, which are not found to be true representatives of the market conditions in Pakistan. Many of the earlier studies, for example by Khan and Ahmed (1990), have termed the rate of return on time deposits of different maturity periods as a better opportunity cost variable to be used in the money demand specification. Moreover, cointegral relationships of the rate of return on time deposits of different maturity periods have been found with real money balances in the case of Pakistan see Ali (1994). In this situation, by taking rate of return on time deposits of one year as the short-term rate and the interest rate on time deposits of more than three years maturity period as the long-term interest rate, the results of the study can be improved.

Second, the use of the sample period which extends over decades when Bangladesh was a part of Pakistan, makes this an exercise for illustrative purposes 
only. On the other hand, the estimation for the sub-sample period, 1972-91, makes the sample size too small to employ this technique. In this circumstance, the use of quarterly data can resolve some of the problems relating to sample size. Of course, the use of the quarterly data would not affect the long-run relationship between the variables, but it will increase the sample size sufficiently large so as to improve the validity of the results achieved. Quarterly data is easily available for all variables of money demand specification except for GDP. However, quarterly series of GDP can be generated by using standard techniques as has been done by Khan (1994).

Finally, this paper identifies a stable long run money demand relationship. This finding is important because during the 1980s Pakistan has experienced various reforms, especially exchange rate reforms, debt management reforms and interest rate liberalisation. These changes in the financial sector do not have any significant impact on the long-run behaviour of the money demand. It may, however, be the case that the changes in the financial environment have not affected the long-run relationship of money demand but might have rendered somewhat unpredictable short-run deviations from the long-run equilibrium. Such deviations obviously have their implications for policy purposes. There are standard tests like CUSUM or CUSUMSO which can be employed to ascertain whether the money demand relationship exhibits predictable short-run behaviour or not.

Syed Sajid Ali

H. 76-R Block 2,

PECH Society,

Karachi.

\section{REFERENCES}

Khan, Ashfaque H. (1994) Financial Liberalisation and the Demand for Money in Pakistan. The Pakistan Development Review 33:4 Part II.

Khan, Ashfaque H., and Mushtaq Ahmed (1990) A Re-examination of the Stability of the Demand for Money in Pakistan. Joumal of the Macroeconomics 12: 2 307-321.

Ali, Syed Sajid (1994) Financial Liberalisation, Money Demand and Monetary Policy in Pakistan. An Unpublished M. Phil dissertation. Islamabad. 